\title{
Exports, Imports, and Profitability in Thai Manufacturing: Evidence from Establishment-level Analysis
}

\author{
Thanapol Srithanpong ${ }^{1}$ \\ ${ }^{1}$ Graduate School of Business and Commerce, Keio University, Tokyo, Japan \\ Correspondence: Thanapol Srithanpong, Graduate School of Business and Commerce, Keio University, Tokyo, \\ Japan. E-mail: thanapol.srithanpong@outlook.com
}

Received: October 10, 2014

Accepted: October 24, 2014

Online Published: November 25, 2014

doi:10.5539/ibr.v7n12p77

URL: http://dx.doi.org/10.5539/ibr.v7n12p77

\begin{abstract}
Combining establishment-level data from the 1999-2003 Manufacturing Industry Surveys and the 2007 Industrial Census of Thailand, this paper examines and documents the relationships between establishment-level profitability and three types of international traders - exporters, importers and two-way traders in Thai manufacturing. The main analysis is divided into three parts. First, we empirically measure trader profitability premia for various profit measures such as operating profit, sales profit, and the rate of profit. Second, we test for trader profitability premia by running regressions of different profit measures on trader status using probit estimation to provide further evidence. Third, we examine whether trade activities are related to firm profitability. Comparing between four groups of firms: two-way traders (being both exporters and importers), only exporters, only importers, and firms that do not trade internationally, the results generally reveal that exporters tend to be the most profitable groups of internationally functioning firms. Two-way traders and importers are roughly the same in terms of profit performance, and firms with no trade are the least profitable as there is evidence for international trader profitability premia. We additionally find that there is a positive correlation between being various types of traders and firm profitability. Particularly, being an exporter is mostly and strongly correlated with an increase in sales profit and the rate of profit of a firm.
\end{abstract}

Keywords: exports, imports, international trade, firm profitability, Thailand

\section{Introduction}

Over the past three decades, a vast literature has emerged and investigated the relationships between different forms of international firm activities (i.e., exporting, importing, and foreign direct investment) and various features of firm performance (i.e., productivity, wages, and so forth). One of the most famous topics in this field of literature is the relationship between exports and productivity. Particularly, the relationship between firm productivity and export activities has been explored widely in the micro-econometric analysis of international trade in recent years. Stylized facts and research findings significantly indicate that exporting firms exhibit higher productivity and pay higher wages. In recent times, current studies examine the relationship between productivity and both exports and imports at the establishment level (Wagner, 2013).

The common use of productivity instead of profitability is attributable to the truth that productivity can be detected in almost every firm-level data set, while profitability is not easily observed. Besides, the number of studies on international trade and firm profits is also few (Wagner, 2014). However, there are many data sets that are currently complete enough to evaluate profitability at the firm level. As a result, a new line of empirical studies regarding trade and profits is gradually increasing. On one hand, it can logically be assumed that exporting (and/or importing) should be profitable in the long run, as firms would choose to abstain from it otherwise. While this may be theoretically correct, researchers are keen to inspect the direct relationship and the size effect of exports (and/or imports) and firm profits (Fryges \& Wagner, 2010). On the other hand, considering profitability as supplementary information apart from productivity, it is also appropriate as productivity is only one of several possible idiosyncratic factors that determine profits (Foster et al., 2008). Success of firms as a whole, and especially survival, strictly depends on profitability in the long term (Wagner, 2012). Regarding this matter, evidence from Thailand can be used as a benchmark for future studies and might be served as a case study for other countries for at least two reasons. First, Thai manufacturing is broad-based, covering from traditional labor-intensive industries to several capital-intensive industries, and appears to be one of the most 
successful cases for industrialization among other developing countries. Second, Thailand is one of the leading actors in Southeast Asian countries and has been an active exporting and importing country and is also the main manufacturer of various goods such as food products, automotive, electronics, and electrical appliances in the world market. Accordingly, empirical evidence from Thai manufacturing concerning this topic should extends the literature and provide a good model at least for other developing countries.

This paper contributes to this emerging body of literature by combining available establishment-level data in Thai manufacturing to conduct the first and comprehensive empirical study on the relationship between firm trade and profitability. Two data sets from the National Statistical Office of Thailand are combined and utilized for the analysis, namely, the 1999-2003 Manufacturing Industry Surveys and the 2007 Industrial Census. We divide our main analysis into three parts. First, we measure international trader (two-way trader, exporter, and importer) profitability premia for various firm profit measures such as operating profit, sales profit, and the rate of profit in a firm. Second, we test for trader profitability premia by running regressions of different profit measures on trader status using probit estimation to provide further evidence. Third, we examine whether trade activities are related to profitability at the establishment level. The main contribution of this paper is that we construct and utilize various profit measures (apart from the commonly used rate of profit - profit margins, we also apply operating profit and sales profit for comparison) in the analysis. This study adds to the trade literature evidence for the relationship between trade and firm profitability from the viewpoint of Thai manufacturing industries. This research intends to push forward the new research area concerning the connection between international trade and firm profitability, especially in the case of newly industrialized and developing countries where there is a scarcity of empirical evidence compared to those of developed countries.

\section{Literature Review}

Involving the issue of firm trade and profitability in recent years, only few empirical studies coping with firm trade and profitability have been included to the firm heterogeneity literature. By and large, the relationship between international trader and profitability at the establishment level is still not well-documented, especially for those of newly industrialized and developing countries. The assumption of firm profit maximization is often the core of rudimentary economic theory. While the perception of international firms being more productive than domestic firms is generally well-documented, empirical evidence concerning the subject whether this productive advantage transforms into higher profitability is much less conclusive (Wagner, 2012). Specifically, the combination of higher revenues associated with access to the international market and higher costs in international trading firms renders the net effect on firm-level profitability unclear. The lack of empirical studies on the relationship between firm profitability and trade activities usually stems from data limitations. To date, little research has been conducted for this topic. Initially, Girma et al. (2004) utilize a non-parametric approach based on the principle of first order stochastic dominance (i.e., a series of Kolmogorov-Smirnov tests) to compare plant performance. The authors find that the distributions for multinationals dominate that of domestic exporters and non-exporters, but do not find clear differences in plant performance between domestic exporters and non-exporters. Kox and Rojas-Romagosa (2010) present evidence for the Dutch firm/plant-level data in the manufacturing and services sectors. Their results indicate that profitability in exporting firms is higher and that more profitable firms self-select into exporting, but evidence for the learning-by-exporting hypothesis is not found. To the best of our knowledge, direct research in this topic has explicitly started from a study by Fryges and Wagner (2010) for German manufacturing enterprises. In that paper, the authors document a small exporter premium on profit margins by statistical analysis and various regression techniques. However, they also show that being an exporter does not significantly increase profits and present empirical evidence suggesting an inverted U-shaped correlation between the export share and profits. Next, Grazzi (2012) reports no significant relationship between exporting and profitability in Italian companies. Recently, Temouri et al. (2013) demonstrate several results for a positive relationship between service exporting and profitability in France, and a negative relationship in Germany. For the theoretical aspect, a notable study to clearly take into account the issue of profitability (such as price mark-ups) is that of Melitz and Ottaviano (2008) indicating that there is only a subset of the more productive firms that are able to export. Profitability is assigned permanently with the draw of a firm's productivity. Hence, more productive firms will enjoy higher mark-ups in an open economy.

For Thai manufacturing so far, there has been no complete study regarding the relationship between international trade and firm profitability at the micro level due to data constraints in the past. Fortunately in recent years, there are now some available datasets that are rich enough for the establishment-level examination in the Thai case. The work in this study can be considered the first and comprehensive empirical study for the Thai case and should be treated as an innovative step for further extensions when more data are available in the future. 


\section{Data, Variable Construction and Empirical Methodology}

For the manufacturing sector in Thailand at the time of this research, there are two types of data which will be used for the establishment-level analysis in this study.

First, the micro-level data in Thai manufacturing can be found in the Manufacturing Industry Survey by the National Statistical Office (NSO) of Thailand, which covers data from 1991 to recent years. In this paper, only the Manufacturing Industry Surveys by the NSO from the years 1999, 2000, 2001, and 2003 are electronically obtainable and utilized in our analysis. Originally, there were 8,552, 9,360, 9,294, and 8,862 observations in the 1999, 2000, 2001, and 2003 surveys, respectively. Of these, we only use observations which are enumerated in the survey (i.e., by a firm which really exists and responds to the survey). The sample observations were therefore lowered to 8,552, 4,658, 4,962, and 8,862 observations in the 1999, 2000, 2001, and 2003 surveys, respectively. After the data-cleaning procedure, the total number of samples dropped from 36,068 to 27,034 observations from a total of four years for the dataset from the Manufacturing Industry Surveys.

Second, more comprehensive samples are available in the National Statistical Office's Industrial Census for 1997 and 2007 (data collected in 1996 and 2006, respectively). The 1997 and 2007 censuses are by far the most comprehensive data available on Thai manufacturing. However, the main drawback of this census data is that it is cross-sectional data, which limits its use for sophisticated research methodology such as panel data analysis. We use a detailed data set at the plant level from the 2007 Industrial Census of Thailand. This data set was conducted by the NSO which surveyed all establishments in 2006. The information is one of the most extensive sets of Thai industrial census data. The original sample size consists of 73,931 observations. Of these, 62,723 are enumerated observations (plants which were still in existence at the time the census was conducted). Due to missing information for many key variables, the census was cleaned up before being used for the analysis.

As described in more detail in Ramstetter (2004), there are some duplicated records in both the data from Manufacturing Surveys and the Industrial Census. The procedure followed to address this problem was to treat the records that reported the same value for the seven key variables of interest in this study as one record. Industries that are either for serving niches in the service sector's domestic market or are explicitly preserved for local enterprises were excluded for the Census data. As a result, the final dataset for the 2007 Industrial Census contains 49,432 observations in 115 industries at the 4-digit ISIC industry level and 22 industries at the 2-digit ISIC industry level. These observations will be the second main sample used for the analysis in this paper. As shown below, the statistical summary and correlation matrix of the key variables employed in the study are summarized in Table 1 and Table 2, respectively.

Table 1. Statistical summary of the key variables

\begin{tabular}{|c|c|c|c|c|c|c|}
\hline Variable & Unit & Obs & Mean & Std. Dev. & Min & Max \\
\hline \multicolumn{7}{|c|}{ Manufacturing Surveys (1999-2003) } \\
\hline $\ln ($ Operating Profit) & (ln) baht & 2031 & 14.00764 & 2.44421 & 4.369448 & 22.0316 \\
\hline $\ln ($ Employees $)$ & (ln) workers & 27029 & 3.414277 & 1.480839 & 0 & 9.765834 \\
\hline Two-Way Trader & zero-one dummy & 27034 & 0.139713 & 0.3466954 & 0 & 1 \\
\hline Exporter & zero-one dummy & 27034 & 0.2150625 & 0.4108733 & 0 & 1 \\
\hline Importer & zero-one dummy & 27034 & 0.2583783 & 0.4377511 & 0 & 1 \\
\hline \multicolumn{7}{|c|}{ Industrial Census (2007) } \\
\hline $\ln ($ Operating Profit) & (ln) baht & 4280 & 12.51502 & 3.174019 & 3.091043 & 22.82248 \\
\hline $\ln$ (Sales Profit) & (ln) baht & 49380 & 14.11438 & 2.628411 & 5.298317 & 25.13578 \\
\hline $\ln$ (Rate of Profit) & (ln) proportion & 49011 & 0.2797566 & 0.2666292 & -5.349608 & 0.6931471 \\
\hline $\ln$ (Employees) & (ln) workers & 49432 & 2.361733 & 1.410629 & 0.6931472 & 9.262174 \\
\hline Two-Way Trader & zero-one dummy & 49432 & 0.0477424 & 0.2132227 & 0 & 1 \\
\hline Exporter & zero-one dummy & 49432 & 0.0781275 & 0.2683749 & 0 & 1 \\
\hline Importer & zero-one dummy & 49432 & 0.0840953 & 0.2775335 & 0 & 1 \\
\hline
\end{tabular}

Note. Mean = simple average $;$ Std. Dev. = standard deviation $;$ Min = minimum $;$ and Max = maximum. 
Table 2. Correlation matrix of the key variables

\begin{tabular}{|c|c|c|c|c|c|c|c|}
\hline Manufacturing Surveys & $\ln ($ Operating Profit) & $\ln$ (Employees) & Two-Way Trader & Exporter & Importer & & \\
\hline $\ln ($ Operating Profit) & 1.000 & & & & & & \\
\hline $\ln$ (Employees) & 0.752 & 1.000 & & & & & \\
\hline Two-Way Trader & 0.351 & 0.508 & 1.000 & & & & \\
\hline Exporter & 0.405 & 0.580 & 0.770 & 1.000 & & & \\
\hline Importer & 0.342 & 0.451 & 0.683 & 0.468 & 1.000 & & \\
\hline Industrial Census & $\ln ($ Operating Profit) & $\ln$ (Sales Profit) & $\ln$ (Rate of Profit) & $\ln ($ Employees $)$ & Two-Way Trader & Exporter & Importer \\
\hline $\ln$ (Operating Profit) & 1.000 & & & & & & \\
\hline $\ln$ (Sales Profit) & 0.785 & 1.000 & & & & & \\
\hline $\ln$ (Rate of Profit) & 0.060 & -0.030 & 1.000 & & & & \\
\hline $\ln$ (Employees) & 0.648 & 0.804 & -0.140 & 1.000 & & & \\
\hline Two-Way Trader & 0.401 & 0.413 & 0.015 & 0.438 & 1.000 & & \\
\hline Exporter & 0.455 & 0.480 & 0.016 & 0.503 & 0.769 & 1.000 & \\
\hline Importer & 0.480 & 0.466 & 0.017 & 0.458 & 0.739 & 0.553 & 1.000 \\
\hline
\end{tabular}

Regarding the definition of profits used in this paper. Various profit measures are calculated and utilized from the available data. There are three types of profit measures which are employed in the analysis. The explanation of each type of firm profit is as follows.

First, operating profit, defined as total receipts of establishment net of total expenses of business and operation of establishment, reflects the profit earned from a firm's other core business operations apart from normal profits derived from total sales. Total receipts include receipts from sales of goods purchased for resale, receipts from contract and commission work, receipts from repair and installation work, receipts from rent on land, receipts from rent on vehicle and building, receipts from dividend and interest received, gain from currency exchange and other receipts. Total expenses include expenses for advertising and transportation, expenses for commission and insurance premium, expenses for electricity and water supply, expenses for accounting and consulting service, expenses for entertainment cost, expenses for postage and internet service, expenses for stationery and wastage materials, expenses for planning and development, expenses from rent on machinery and equipment, expenses for rent on land and building, expenses from training cost, expenses from bad debt and interest paid, loss from currency exchange and other expenses. Operating profit is important because it is one of the indirect measures for firm efficiency. The higher the operating profit, the more profitable a firm's business is. Operating profit is also a measure of managerial flexibility and competency. In our analysis, operating profit can be calculated from the data in both the 1999-2003 Manufacturing Surveys and the 2007 Industrial Census. However, less than half of the observation in the data report full information regarding variables necessary to correctly calculate the operating profit. As a result, only unbiased and fully reported observations are used to compute this profit measure.

\section{Operating Profit $=$ Total Operating Receipts - Total Expenses of Business and Operation}

Second, sales profit, defined as the difference between revenue from total sales and the cost of making products before deducting taxation and interest payments, reflects gross profit of a firm that is primarily the difference between total sales and total production costs. Total sales include every type of sales of goods produced. Total production costs include cost of fuel and electricity for production process, cost of materials and components, cost of repair and maintenance of goods, cost of repair and maintenance of machinery and equipment and other costs. Sales profit is a firm's residual profit after selling products and deducting costs associated with its production. Sales profit (or gross profit) is essential because it indicates how efficiently management uses labor and supplies in the production process.

$$
\text { Sales Profit }=\text { Total Sales }- \text { Total Production Costs }
$$

Third, following Wagner (2012), the rate of profit of a firm is computed as gross firm surplus (computed as gross value added minus total remunerations paid by the firm) divided by total sales minus net change of inventories: 


\section{Rate of Profit $=\frac{\text { Gross Value Added }- \text { Total Remunerations }}{\text { Total Sales }- \text { Net Change of Inventories }}$}

Specifically, gross value added is calculated from the difference between gross output and total costs of production and expenditure of establishment. Total remunerations include gross wages, salaries, bonuses, and costs for medical care and social insurance paid by the firm. This profit measure is a measure for the price-cost margin which, under competitive conditions, should generally equal the required rental on assets employed per money unit of sales (Wagner, 2012). In terms of our economic analysis, the rate of profit here is used as a proxy for the profit margin (the ratio of net income to net sales) in accounting.

Regarding limitations on the definition of profits in this paper, the main constraint points to the characterization and computation of firm profits. Apart from listed companies in the stock exchange market, the information concerning firm profits (i.e., net profit, operating profit and sales profit) is not easily observed. As a result, there are three important points that should be discussed regarding firm profit measures used in our analysis.

First, due to data unavailability and limitations, sales profit and the rate of profit can only be observed and calculated precisely from the 2007 Industrial Census, not from the 1999-2003 Manufacturing Surveys since the surveys do not provide enough information for the reliable and correct computation of sales profit and the rate of profit. Second, firm-level data (the 1999-2003 Manufacturing Surveys in our analysis) might be considered multi-market aggregates, while data constructed at the plant level (the 2007 Industrial Census in our analysis) do not reflect costs incurred at the firm level, and the allocation of those costs to individual lines of business is inevitably rather arbitrary. Moreover, since firm/plant profit measures are relatively difficult to observe comparing to other firm/plant performance measures (e.g., labor productivity, value added, average wages, and so forth), our profit measures, albeit correctly computed by economic definition, might be subject to biases both in terms of overestimation and underestimation in terms of accounting standard. In view of the fact that the initial data set does not provide data in the accounting standard form, it is certainly impossible to correctly detect the exact values of profits at the establishment level in our analysis. However, our calculated profit measures can be considered consistent and reliable since we carefully exclude observations that do not provide enough information for firm profit computation. Nevertheless, our profit measures should be taken as a first step for further extensions and/or replications with richer micro-level data available in the future. Third, as summarized in Table 1 for the total observation in this study, it is important to note that the observation number may differ when regressing and estimating each model depending on the dependent and independent variables used in the specification. The reasons for changing number of observations are twofold. On one hand, observations with extreme values (heavily influential outliers that have extreme values of observed variables distorting estimates of regression coefficients) may be dropped during the estimation to preserve the reliable and consistent estimated results. On the other hand, depending on the variable and estimation technique utilized in the calculation, estimation results may demonstrate slightly fewer observations than the original observation shown in Table 1 because some observations are naturally omitted due to insufficient information and missing values.

Concerning the main methodology employed in the investigation of the existence of trader profitability premia, as widely used in trade empirics and similar to trader productivity premia (especially for export premia), profitability premia can be calculated from a regression of log profit measures on the current trade status dummy variables and a set of control variables. The fundamental equation can simply be written as follows:

$$
\text { InProfit }_{i t}=\beta_{0}+\beta_{l} \text { Trader }_{i t}+\beta_{2} \text { Control }_{i t}+\sigma_{i t}
$$

where $i$ is the index of the firm or plant, $t$ is the index of the year, Profit is firm profit measures, Trader is a dummy variable for current trade status (two-way trader, exporter, importer), Control is a vector of control variables (industry dummies, dummies for regions, firm size, and year dummies), and $\sigma$ is an error term. The trader profitability premia, calculated from the estimated coefficient $\beta_{1}$, shows the average percentage difference between traders and non-traders that controls for the characteristics included in the Control vector.

\section{International Trader Profitability Premia in Thai Manufacturing}

The first step of our empirical investigation into the relationship between international trader and firm profitability is the estimation of trader profitability premia. We estimate profitability premia with a regression that controls for industry affiliation (to control for industry specific effects and to proxy differences in the unobserved capital intensity between industries), region (to control for location specific effects) and firm size and capacity (measured by the number of employees). The empirical model is estimated using the data from both the 1999-2003 Manufacturing Surveys and the 2007 Industrial Census, and year dummy variables are included for the analysis using the 1999-2003 Manufacturing Surveys. In this stage, the model is chiefly estimated by 
OLS (Ordinary Least Squares). To test for trader profitability premia, we run regressions of the different profit measures on trader status (two-way trader, exporter and importer) with and without controls for comparison. We estimate the following regressions:

$$
\text { InProfit }_{i}=\alpha+\beta \text { Trader }_{i}+\gamma \text { Industry }_{i}+\delta \text { Region }_{i}+\mu \text { Size }_{i}+\varepsilon_{i}
$$

Profit $_{i}$ represents three measures of firm profit performance: operating profit (total operating receipts minus total expenses of business and operation), sales profit (total sales minus total production costs), and the rate of profit (the ratio of gross firm surplus to total sales net change of inventories). Trader $r_{i}$ is a dummy variable for current trader status ( 1 if a firm is a two-way trader or exporter or importer, 0 otherwise). Industry and $_{i}$ Region are $_{\text {are }}$ dummy variables for the two-digit industry (total 20 industries for the Surveys and total 22 industries for the Census) and region where a firm is located (total 6 regions - Bangkok, Vicinity and Central, Northern, Northeastern, Southern, and Others). Size ${ }_{i}$ denotes firm size, measured by number of employees: Small being 1 15 persons, Medium being $16-100$, and Large being more than 101 persons.

The estimated results for trader profitability premia from Equation (2) are reported in Table 3 for the years 1999, 2000, 2001, 2003 (data from the Manufacturing Surveys) and 2007 (data from the Industrial Census). As can be seen, controlling for industry and region has little effect on the magnitude of the trader profitability premia. However, controlling for firm size greatly and significantly reduces the coefficient of the trader dummy variable when compared with both the estimated results without controls and results with only industry and region controlled. This suggests that, to a large extent, the necessary characteristics of international traders might be inferable to their larger size. Consequently, we mainly refer the estimated results controlling for industry, region and size effects as our benchmark results in Table 3. The estimated results can be explained as follows.

For the period 1999-2003 (data from the Manufacturing Surveys), trader profitability premia, as measured by the operating profit, usually reveal that exporters tend to exhibit the highest estimated values of profitability premia (ranging from 79-141\%). Two-way traders generally exhibit the second highest estimated values of profitability premia (ranging from 76-135\%) and importers are always ranked last in terms of operating profit (ranging from 54-75\%). On average, the estimated results from the 1999-2003 Manufacturing Surveys reveal that exporters are the most profitable groups of international traders.

Nonetheless, for the year 2007 (data from the Industrial Census), the estimated results for trader profitability premia are not conclusive. When looking at the operating profit, importers are conversely the most profitable groups of international traders (operating profit premia are equal to $125 \%$ and highest for importers) compared to the results from the surveys. For the sales profit, it is shown that exporters again tend to be the most profitable groups of international traders (sales profit premia are equal to $133 \%$ and highest for exporters). For the rate of profit, two-way traders exhibit the highest values of estimated profitability premia (the profitability premia in terms of the rate of profit are equal to $2.94 \%$ and highest for two-way traders). Since there exists significant evidence for trader profitability premia among internationally active firms, it can be inferred that firms/plants that do not trade internationally are likely to be the least profitable groups of firms.

For Table 4 to Table 6, similar to the results from Table 3, controlling for firm size greatly reduces the coefficients of the trader dummy variable. This again suggests that the desirable characteristics of international traders are due to their larger size. Accordingly, we only refer to the estimated results controlling for industry, region and size effects as our benchmark results from Table 4 to Table 6, and discuss the estimated results separately for the two datasets. We begin first with the results from the 1999-2003 Manufacturing Surveys. For the operating profit measure, the marginal effects for exporters tend to exhibit the largest values compared to other international traders. Being an exporter increases the probability of an improvement in the operating profit by $2.46 \%$. Being an importer improves the probability of an enhancement in the operating profit by $1.49 \%$. Lastly. Being a two-way trader only add to the probability of an improvement in the operating profit by $0.81 \%$.

For the 2007 Industrial Census, the overall estimated results for trader profitability premia notably reveal that importers are most likely to enjoy profitability premia in every profit measure. The coefficients and marginal effects are shown to be the largest in the case of importers, then exporters, and two-way trades usually come last. For the operating profit, being an importer increases the probability of an improvement in the operating profit by $0.89 \%$ ( $0.45 \%$ for exporters and $0.1 \%$ for two-way traders). For the sales profit, being an importer improves the probability of an enhancement in the sales profit by $1.08 \%$ ( $0.64 \%$ for exporters and $0.13 \%$ for two-way traders). In terms of the rate of profit, being an importer increases the probability of an improvement in the rate of profit by $2.19 \%$ ( $1.75 \%$ for exporters and $0.57 \%$ for two-way traders).

In conclusion, from Table 4 to Table 6, we can see that exporters (especially from 1999 to 2003) and importers (especially in 2007) tend to be the most profitable groups of international traders. Combining the results from 
Table 3 to Table 6 , it is clear that there exist profitability premia for international traders (two-way traders, exporters and importers). On the whole, exporters tend to be the most profitable group of international traders, especially in terms of operating profit. Our results are in line with the theoretical prediction that exporters are the most productive groups of firms in general, and this productivity advantage might translate into profitability advantage as suggested by the empirical evidence. We can also conclude that firms/plants that do not engage in exporting and/or importing activities tend to be the least profitable firms since there exists empirical evidence for international trader profitability premia that is statistically significant in our analysis.

Table 3. International trader profitability premia in Thai manufacturing

\begin{tabular}{|c|c|c|c|c|}
\hline & \multicolumn{4}{|c|}{ Estimated Two-Way Trader Profitability Premia (\%) } \\
\hline & No control & Industry controlled & Industry and Region controlled & Industry, Region and Size controlled \\
\hline \multicolumn{5}{|l|}{1999} \\
\hline \multirow[t]{2}{*}{ Operating Profit } & $267.14 \%$ & $246.23 \%$ & $227.31 \%$ & $135.73 \%$ \\
\hline & $(10.56)$ & $(9.38)$ & $(9.51)$ & $(6.21)$ \\
\hline Observations & 603 & 603 & 603 & 603 \\
\hline \multicolumn{5}{|l|}{2000} \\
\hline \multirow[t]{2}{*}{ Operating Profit } & $284.06 \%$ & $324.50 \%$ & $291.13 \%$ & $111.45 \%$ \\
\hline & $(4.74)$ & $(6.38)$ & $(5.2)$ & $(2.18)$ \\
\hline Observations & 299 & 299 & 299 & 299 \\
\hline \multicolumn{5}{|l|}{2001} \\
\hline \multirow[t]{2}{*}{ Operating Profit } & $298.30 \%$ & $299.07 \%$ & $272.64 \%$ & $154.50 \%$ \\
\hline & $(7.07)$ & $(6.81)$ & $(7.22)$ & (4) \\
\hline Observations & 353 & 353 & 353 & 353 \\
\hline \multicolumn{5}{|l|}{2003} \\
\hline \multirow[t]{2}{*}{ Operating Profit } & $339.14 \%$ & $345.68 \%$ & $284.23 \%$ & $76.52 \%$ \\
\hline & (14.52) & (14.24) & (11.79) & $(4.04)$ \\
\hline Observations & 776 & 776 & 776 & 776 \\
\hline \multicolumn{5}{|l|}{2007} \\
\hline \multirow[t]{2}{*}{ Operating Profit } & $452.45 \%$ & $370.05 \%$ & $267.29 \%$ & $73.50 \%$ \\
\hline & $(36.04)$ & (26.54) & (19.78) & $(4.67)$ \\
\hline Observations & 4280 & 4280 & 4280 & 4280 \\
\hline \multirow[t]{2}{*}{ Sales Profit } & $509.00 \%$ & $445.53 \%$ & $375.86 \%$ & $100.96 \%$ \\
\hline & (135.37) & (107.03) & (88.54) & (25.64) \\
\hline Observations & 49380 & 49380 & 49380 & 49380 \\
\hline \multirow[t]{2}{*}{ Rate of Profit } & $1.88 \%$ & $2.23 \%$ & $1.33 \%$ & $2.94 \%$ \\
\hline & $(6.02)$ & $(6.61)$ & $(3.85)$ & (7.37) \\
\hline \multirow[t]{3}{*}{ Observations } & 49011 & 49011 & 49011 & 49011 \\
\hline & \multicolumn{4}{|c|}{ Estimated Exporter Profitability Premia (\%) } \\
\hline & No control & Industry controlled & Industry and Region controlled & Industry, Region and Size controlled \\
\hline \multicolumn{5}{|l|}{1999} \\
\hline \multirow[t]{2}{*}{ Operating Profit } & $261.54 \%$ & $246.41 \%$ & $224.36 \%$ & $141.61 \%$ \\
\hline & $(11.61)$ & $(10.59)$ & $(10.2)$ & (7.1) \\
\hline Observations & 603 & 603 & 603 & 603 \\
\hline \multicolumn{5}{|l|}{2000} \\
\hline \multirow[t]{2}{*}{ Operating Profit } & $282.03 \%$ & $285.26 \%$ & $269.26 \%$ & $134.86 \%$ \\
\hline & $(7.01)$ & $(7.65)$ & $(7.54)$ & $(4.05)$ \\
\hline Observations & 299 & 299 & 299 & 299 \\
\hline
\end{tabular}




\begin{tabular}{|c|c|c|c|c|}
\hline \multicolumn{5}{|l|}{2001} \\
\hline \multirow[t]{2}{*}{ Operating Profit } & $235.75 \%$ & $250.73 \%$ & $230.19 \%$ & $135.35 \%$ \\
\hline & $(6.34)$ & $(6.84)$ & $(6.97)$ & $(4.44)$ \\
\hline Observations & 353 & 353 & 353 & 353 \\
\hline \multicolumn{5}{|l|}{2003} \\
\hline \multirow[t]{2}{*}{ Operating Profit } & $346.61 \%$ & $338.72 \%$ & $286.58 \%$ & $79.28 \%$ \\
\hline & (16.61) & (15.66) & (13.07) & $(4.83)$ \\
\hline Observations & 776 & 776 & 776 & 776 \\
\hline \multicolumn{5}{|l|}{2007} \\
\hline \multirow[t]{2}{*}{ Operating Profit } & $438.02 \%$ & $375.46 \%$ & $273.04 \%$ & $98.76 \%$ \\
\hline & (40.37) & (31.88) & (22.76) & $(7.27)$ \\
\hline Observations & 4280 & 4280 & 4280 & 4280 \\
\hline \multirow[t]{2}{*}{ Sales Profit } & $469.87 \%$ & $424.39 \%$ & $361.53 \%$ & $132.99 \%$ \\
\hline & (142.25) & (122.16) & (102.05) & (40.67) \\
\hline Observations & 49380 & 49380 & 49380 & 49380 \\
\hline \multirow[t]{2}{*}{ Rate of Profit } & $1.58 \%$ & $1.74 \%$ & $0.71 \%$ & $2.25 \%$ \\
\hline & $(5.47)$ & $(5.61)$ & $(2.21)$ & $(5.61)$ \\
\hline \multirow[t]{3}{*}{ Observations } & 49011 & 49011 & 49011 & 49011 \\
\hline & \multicolumn{4}{|c|}{ Estimated Importer Profitability Premia (\%) } \\
\hline & No control & Industry controlled & Industry and Region controlled & Industry, Region and Size controlled \\
\hline \multicolumn{5}{|l|}{1999} \\
\hline \multirow[t]{2}{*}{ Operating Profit } & $177.23 \%$ & $150.42 \%$ & $136.41 \%$ & $75.54 \%$ \\
\hline & $(9.29)$ & $(7.44)$ & (7.14) & $(4.59)$ \\
\hline Observations & 603 & 603 & 603 & 603 \\
\hline \multicolumn{5}{|l|}{2000} \\
\hline \multirow[t]{2}{*}{ Operating Profit } & $136.17 \%$ & $127.35 \%$ & $103.85 \%$ & $12.41 \%$ \\
\hline & $(4.06)$ & $(3.45)$ & $(2.84)$ & $(0.45)$ \\
\hline Observations & 299 & 299 & 299 & 299 \\
\hline \multicolumn{5}{|l|}{2001} \\
\hline \multirow[t]{2}{*}{ Operating Profit } & $164.07 \%$ & $146.47 \%$ & $128.86 \%$ & $53.56 \%$ \\
\hline & $(5.15)$ & $(4.32)$ & $(4.06)$ & (2) \\
\hline Observations & 353 & 353 & 353 & 353 \\
\hline \multicolumn{5}{|l|}{2003} \\
\hline \multirow[t]{2}{*}{ Operating Profit } & $278.88 \%$ & $280.75 \%$ & $233.00 \%$ & $54.49 \%$ \\
\hline & (13.6) & (13.53) & (11.46) & $(3.43)$ \\
\hline Observations & 776 & 776 & 776 & 776 \\
\hline \multicolumn{5}{|l|}{2007} \\
\hline \multirow[t]{2}{*}{ Operating Profit } & $442.20 \%$ & $380.30 \%$ & $269.01 \%$ & $125.44 \%$ \\
\hline & (41.13) & (31.35) & $(22.51)$ & $(9.83)$ \\
\hline Observations & 4280 & 4280 & 4280 & 4280 \\
\hline \multirow[t]{2}{*}{ Sales Profit } & $440.96 \%$ & $385.88 \%$ & $314.81 \%$ & $125.14 \%$ \\
\hline & (131.56) & (106.77) & $(86.2)$ & $(42.02)$ \\
\hline Observations & 49380 & 49380 & 49380 & 49380 \\
\hline \multirow[t]{2}{*}{ Rate of Profit } & $1.62 \%$ & $1.77 \%$ & $0.77 \%$ & $1.85 \%$ \\
\hline & $(5.96)$ & $(5.91)$ & $(2.54)$ & $(5.38)$ \\
\hline Observations & 49011 & 49011 & 49011 & 49011 \\
\hline
\end{tabular}

Note. Heteroscedasticity robust t-statistics in parentheses. All coefficients are significant at the 5 percent confidence level or better. 
Table 4. Probit estimation for two-way trader profitability premia (marginal effects)

\begin{tabular}{|c|c|c|c|c|}
\hline \multirow[t]{2}{*}{ Two-Way Trader } & (1) & (2) & (3) & (4) \\
\hline & No control & Industry controlled & Industry and Region controlled & Industry, Region, and Size controlled \\
\hline \multicolumn{5}{|c|}{ Manufacturing Surveys (1999-2003) } \\
\hline \multirow[t]{2}{*}{$\ln ($ Operating Profit) } & $0.0130 * * *$ & $0.0128 * * *$ & $0.0106^{* * *}$ & $0.00811 * * *$ \\
\hline & $(5.06)$ & $(5.21)$ & $(4.20)$ & $(3.82)$ \\
\hline \multirow[t]{2}{*}{$\ln ($ Employees $)$} & $0.0278 * * *$ & $0.0212 * * *$ & $0.0202 * * *$ & $0.0162 * * *$ \\
\hline & $(6.12)$ & $(5.03)$ & $(4.90)$ & $(3.81)$ \\
\hline Years Controlled & No & No & No & Yes \\
\hline Observations & 2031 & 2025 & 2025 & 2025 \\
\hline \multicolumn{5}{|c|}{ Industrial Census (2007) } \\
\hline \multirow[t]{2}{*}{$\ln$ (Operating Profit) } & $0.00541 * * *$ & $0.00302 * * *$ & $0.00154 * *$ & $0.00103^{* *}$ \\
\hline & $(6.69)$ & $(4.79)$ & $(3.25)$ & $(2.64)$ \\
\hline \multirow[t]{2}{*}{$\ln$ (Employees) } & $0.0235^{* * *}$ & $0.0166^{* * *}$ & $0.0115^{* * *}$ & $0.0110 * * *$ \\
\hline & $(10.67)$ & $(7.52)$ & $(6.23)$ & $(5.30)$ \\
\hline Observations & 4280 & 4280 & 4280 & 4280 \\
\hline \multirow[t]{2}{*}{$\ln$ (Sales Profit) } & $0.00329 * * *$ & $0.00221 * * *$ & $0.00169^{* * *}$ & $0.00137 * * *$ \\
\hline & (17.04) & (12.93) & (11.50) & $(8.12)$ \\
\hline \multirow[t]{2}{*}{$\ln$ (Employees) } & $0.00369 * * *$ & $0.00196 * * *$ & $0.00162 * * *$ & $0.00161 * * *$ \\
\hline & (12.73) & $(9.05)$ & $(8.33)$ & $(8.31)$ \\
\hline Observations & 49380 & 49380 & 49380 & 49380 \\
\hline \multirow[t]{2}{*}{$\ln$ (Rate of Profit) } & $0.0160 * * *$ & $0.0119 * * *$ & $0.00715^{* * *}$ & $0.00570 * * *$ \\
\hline & (10.44) & $(9.65)$ & $(7.21)$ & $(6.45)$ \\
\hline \multirow[t]{2}{*}{$\ln$ (Employees) } & $0.0142 * * *$ & $0.00987 * * *$ & $0.00684 * * *$ & $0.00593 * * *$ \\
\hline & (26.02) & (19.15) & (15.53) & (12.65) \\
\hline Observations & 49011 & 49011 & 49011 & 49011 \\
\hline
\end{tabular}

Note. Heteroscedasticity robust $\mathrm{t}$-statistics in parentheses. $* * *, * *$, and $*$ represent significance at $1 \%, 5 \%$, and $10 \%$ confidence levels, respectively.

Table 5. Probit estimation for exporter profitability premia (marginal effects)

\begin{tabular}{|c|c|c|c|c|}
\hline \multirow[t]{2}{*}{ Exporter } & (1) & (2) & (3) & (4) \\
\hline & No control & Industry controlled & Industry and Region controlled & Industry, Region, and Size controlled \\
\hline \multicolumn{5}{|c|}{ Manufacturing Surveys (1999-2003) } \\
\hline \multirow[t]{2}{*}{$\ln ($ Operating Profit) } & $0.0271 * * *$ & $0.0289 * * *$ & $0.0277 * * *$ & $0.0246 * * *$ \\
\hline & $(7.16)$ & $(7.50)$ & $(6.65)$ & $(6.22)$ \\
\hline \multirow[t]{2}{*}{$\ln ($ Employees $)$} & $0.0363^{* * *}$ & $0.0303 * * *$ & $0.0303^{* * *}$ & $0.0197 * *$ \\
\hline & $(5.74)$ & $(4.86)$ & $(4.80)$ & $(2.72)$ \\
\hline Years Controlled & No & No & No & Yes \\
\hline Observations & 2031 & 2025 & 2025 & 2025 \\
\hline
\end{tabular}




\begin{tabular}{|c|c|c|c|c|}
\hline \multicolumn{5}{|c|}{ Industrial Census (2007) } \\
\hline \multirow[t]{2}{*}{$\ln$ (Operating Profit) } & $0.0102 * * *$ & $0.00796 * * *$ & $0.00523^{* * *} *$ & $0.00451 * * *$ \\
\hline & $(8.33)$ & $(6.79)$ & $(4.68)$ & (4.14) \\
\hline \multirow[t]{2}{*}{$\ln ($ Employees $)$} & $0.0429 * * *$ & $0.0375^{* * *}$ & $0.0323^{* * *}$ & $0.0340^{* * *}$ \\
\hline & $(14.57)$ & (12.54) & (11.19) & $(10.29)$ \\
\hline Observations & 4280 & 4280 & 4280 & 4280 \\
\hline \multirow[t]{2}{*}{$\ln$ (Sales Profit) } & $0.00890 * * *$ & $0.00829 * * *$ & $0.00700^{* * *}$ & $0.00640 * * *$ \\
\hline & $(24.83)$ & $(23.32)$ & (20.46) & (15.89) \\
\hline \multirow[t]{2}{*}{$\ln ($ Employees $)$} & $0.0122 * * *$ & $0.00917 * * *$ & $0.00845^{* * *}$ & $0.00872 * * *$ \\
\hline & $(19.70)$ & $(16.19)$ & $(15.71)$ & $(15.21)$ \\
\hline Observations & 49380 & 49380 & 49380 & 49380 \\
\hline \multirow[t]{2}{*}{$\ln$ (Rate of Profit) } & $0.0342 * * *$ & $0.0305^{* * *}$ & $0.0188^{* * *}$ & $0.0175^{* * *}$ \\
\hline & $(10.05)$ & $(9.79)$ & $(6.86)$ & $(6.79)$ \\
\hline \multirow[t]{2}{*}{$\ln$ (Employees) } & $0.0337 * * *$ & $0.0297 * * *$ & $0.0239 * * *$ & $0.0230^{* * *}$ \\
\hline & $(40.62)$ & $(35.97)$ & $(29.81)$ & $(26.91)$ \\
\hline Observations & 49011 & 49011 & 49011 & 49011 \\
\hline
\end{tabular}

Note. Heteroscedasticity robust $\mathrm{t}$-statistics in parentheses. ***, **, and * represent significance at $1 \%, 5 \%$, and $10 \%$ confidence levels, respectively.

Table 6. Probit estimation for importer profitability premia (marginal effects)

\begin{tabular}{|c|c|c|c|c|}
\hline \multirow[t]{2}{*}{ Importer } & (1) & (2) & (3) & (4) \\
\hline & No control & Industry controlled & Industry and Region controlled & Industry, Region, and Size controlled \\
\hline \multicolumn{5}{|c|}{ Manufacturing Surveys (1999-2003) } \\
\hline \multirow[t]{2}{*}{$\ln ($ Operating Profit) } & $0.0280 * * *$ & $0.0198 * * *$ & $0.0147 *$ & $0.0149 * *$ \\
\hline & $(5.35)$ & $(3.63)$ & $(2.54)$ & $(2.67)$ \\
\hline \multirow[t]{2}{*}{$\ln ($ Employees $)$} & $0.0637 * * *$ & $0.0742 * * *$ & $0.0754 * * *$ & $0.0652 * * *$ \\
\hline & (7.33) & $(8.16)$ & $(8.25)$ & $(5.34)$ \\
\hline Years Controlled & No & No & No & Yes \\
\hline Observations & 2031 & 2025 & 2025 & 2025 \\
\hline \multicolumn{5}{|c|}{ Industrial Census (2007) } \\
\hline \multirow[t]{2}{*}{$\ln ($ Operating Profit) } & $0.0192 * * *$ & $0.0147 * * *$ & $0.00948 * * *$ & $0.00892 * * *$ \\
\hline & $(12.32)$ & $(9.75)$ & $(6.66)$ & $(6.17)$ \\
\hline \multirow[t]{2}{*}{$\ln$ (Employees) } & $0.0404 * * *$ & $0.0356^{* * *}$ & $0.0296^{* * *}$ & $0.0321 * * *$ \\
\hline & $(12.15)$ & (10.86) & $(9.79)$ & $(7.95)$ \\
\hline Observations & 4280 & 4280 & 4280 & 4280 \\
\hline \multirow[t]{2}{*}{$\ln$ (Sales Profit) } & $0.0165^{* * *}$ & $0.0140^{* * *}$ & $0.0109 * * *$ & $0.0108^{* * *}$ \\
\hline & (33.86) & (29.19) & $(23.60)$ & (21.43) \\
\hline \multirow[t]{2}{*}{$\ln$ (Employees) } & $0.00783^{* * *} *$ & $0.00626^{* * *}$ & $0.00661 * * *$ & $0.00677 * * *$ \\
\hline & (11.53) & $(9.61)$ & (10.62) & (8.19) \\
\hline Observations & 49380 & 49380 & 49380 & 49380 \\
\hline \multirow[t]{2}{*}{$\ln$ (Rate of Profit) } & $0.0500^{* * *}$ & $0.0396^{* * *}$ & $0.0221^{* * *}$ & $0.0219 * * *$ \\
\hline & (12.00) & $(9.98)$ & $(6.79)$ & $(6.86)$ \\
\hline \multirow[t]{2}{*}{$\ln$ (Employees) } & $0.0443^{* * * *}$ & $0.0364 * * *$ & $0.0269 * * *$ & $0.0275 * * *$ \\
\hline & (55.48) & $(45.32)$ & (33.89) & (31.30) \\
\hline Observations & 49011 & 49011 & 49011 & 49011 \\
\hline
\end{tabular}

Note. Heteroscedasticity robust $\mathrm{t}$-statistics in parentheses. $* * *, * *$, and $*$ represent significance at $1 \%, 5 \%$, and $10 \%$ confidence levels, respectively. 


\section{International Trade and Profitability in Thai Manufacturing}

In this section, we attempt to basically test for the first time in Thai manufacturing the relationship between international trade and profitability at the establishment level. The findings in this section should help emphasize and shed light on the relationship between international trade and firm profitability in Thai manufacturing and add to the growing body of knowledge in this field of trade literature. The estimated results are shown Table 7 for the operating profit and Table 8 for the sales profit and the rate of profit. Regarding the estimator used in this section, three estimation techniques are used to compare the results: OLS regression (least squares regression with White's heteroscedasticity robust t-statistics), robust OLS regression (least squares regression when eliminating from the data set the influential observations, that is, the outliers and/or the explanatory variables significantly deviated from mean judged in terms of Cook's distance measure), and Quantile regression (median regression technique intended to estimate conditional quantile functions and give a more comprehensive picture of the effect of the independent variables on the dependent variable). As fully shown in Table 7 and Table 8, the estimated coefficients from various estimators exhibit the same sign and are in line with the theoretical expectation and only differ in magnitude, confirming our initial careful consideration of the observations used in calculating profit measures. Generally, robust OLS and quantile regressions can be considered more efficient than normal OLS regression when there are many potential and influential outliers in the data. As a result, in this section, we will mainly refer to the estimated results from the robust OLS and quantile regressions as our benchmark results for the analysis.

We start with the analysis of the estimated results for the relationship between international trade and the operating profit in Table 7. For the results from the 1999-2003 Manufacturing Surveys, we observe that international trade is positively correlated with firm profitability in terms of the operating profit. Specifically, being an exporter is associated with an increase in the operating profit by $46-57 \%$. Being a two-way trader leads to an increase in operating profit by $39-41 \%$ and being an importer only results in an improvement in the operating profit by approximately $18.8 \%$. For the results from the 2007 Industrial Census, engaging in imports is associated with an increase in the operating profit by $87 \%$. Engaging in exports is associated with an increase in the operating profit by 53-60\%. Lastly, engaging in both exports and imports (being two-way traders) is associated with an increase in the operating profit by approximately $36 \%$.

From Table 8, the relationships between international trade and alternative profit measures are empirically revealed. The overall results suggest that there are positive relationships between trade and firm profitability by various measures. In terms of sales profit, exporters and importers appear to be equally profitable on average (engaging in exports or imports is associated with an increase in sales profit by roughly 62\%), while two-way traders are associated with an increase in sales profit by roughly 57\%. With regard to the rate of profit, being an exporter is linked with an expansion for the rate of profit by $3.9-4.5 \%$. Being an importer or a two-way trader is linked with an expansion for the rate of profit by roughly 3\% (3.1-3.2\% for importers and 2.8-3.4\% for two-way traders, specifically). All the estimated results are highly significant.

Summing up the findings from Table 7 and Table 8, it is clearly revealed that profitability is indeed positively correlated with international trade activities (exports, imports and two-way trade). Exporters tend to be the most profitable groups of internationally active firms that trade across countries, especially in terms of the sales profit and the rate of profit. Two-way traders and importers are approximately the same in terms of profit performance and firms with no trade can be expected to be the least profitable firms. One important insight that emerges from our estimated results and should be highlighted is that productivity and profitability are truly correlated from empirical evidence in Thai manufacturing. As well-documented in various empirical studies, exporters tend to be the most productive firms and pay higher average wages when compared to other types of firms. From our empirical results, exporters are, on average, the most profitable groups in Thai manufacturing from the analysis.

Comparing our estimated results with those of the previous study (e.g., Fryges and Wagner, 2010; Wagner, 2012), our results are generally in line with Fryges and Wagner (2010) for German manufacturing that there also exist trader profitability premia among international traders in Thai manufacturing. Remarkably for the premia in terms of the rate of profit, this differential premia is rather small both in the German and Thai cases. However, while findings reported in Wagner (2012) show the absence of any statistically and economically large effects of trade activities on profits for the German case, a positive profitability differential of traders compared to non-traders in our analysis for the Thai case is strongly and statistically significant. Furthermore, we find robust evidence for positive relationships between trade and firm profitability by various profit measures. This may imply that, unlike the German case, productivity advantages of trading firms in the Thai case are not totally absorbed by extra costs related to the integration into foreign markets. 
Table 7. International trade and profitability (operating profit)

\begin{tabular}{|c|c|c|c|c|c|c|}
\hline \multirow[b]{3}{*}{$\ln$ (Operating Profit) } & \multicolumn{3}{|c|}{ Manufacturing Surveys (1999-2003) } & \multicolumn{3}{|c|}{ Industrial Census (2007) } \\
\hline & \multicolumn{3}{|c|}{ Two-Way Trader \& Profitability } & \multicolumn{3}{|c|}{ Two-Way Trader \& Profitability } \\
\hline & OLS & Robust OLS & Quantile & OLS & Robust OLS & Quantile \\
\hline \multirow[t]{2}{*}{ Two-Way Trader } & $0.467 * * *$ & $0.392 * * *$ & $0.413 * * *$ & $0.479 * *$ & $0.362 * *$ & 0.274 \\
\hline & $(4.24)$ & $(3.49)$ & $(4.30)$ & $(3.27)$ & $(2.58)$ & $(1.70)$ \\
\hline \multirow[t]{2}{*}{$\ln ($ Employees) } & $1.171 * * *$ & $1.193 * * *$ & $1.182 * * *$ & $0.902 * * *$ & $0.924 * * *$ & $0.944 * * *$ \\
\hline & $(47.78)$ & $(53.76)$ & $(62.71)$ & $(21.74)$ & $(23.37)$ & $(20.69)$ \\
\hline \multirow[t]{2}{*}{ Constant } & $11.12 * * *$ & $10.99 * * *$ & $11.24 * * *$ & $9.816^{* * * *}$ & $9.838 * * *$ & $10.05 * * *$ \\
\hline & $(40.94)$ & $(18.66)$ & $(24.52)$ & $(23.37)$ & $(22.49)$ & $(22.92)$ \\
\hline Industry Controlled & Yes & Yes & Yes & Yes & Yes & Yes \\
\hline Region Controlled & Yes & Yes & Yes & Yes & Yes & Yes \\
\hline Year/Size Controlled & Yes & Yes & Yes & Yes & Yes & Yes \\
\hline Observations & 2031 & 2031 & 2031 & 4280 & 4280 & 4280 \\
\hline \multirow{2}{*}{ Adjusted $\mathrm{R}^{2}$} & 0.646 & 0.695 & & 0.574 & 0.573 & \\
\hline & \multicolumn{3}{|c|}{ Exporter \& Profitability } & \multicolumn{3}{|c|}{ Exporter \& Profitability } \\
\hline $\ln$ (Operating Profit) & OLS & Robust OLS & Quantile & OLS & Robust OLS & Quantile \\
\hline \multirow[t]{2}{*}{ Exporter } & $0.683 * * *$ & $0.573 * * *$ & $0.459 * * *$ & $0.651 * * *$ & $0.608 * * *$ & $0.535^{* * *}$ \\
\hline & $(7.18)$ & $(6.04)$ & $(5.15)$ & $(5.08)$ & $(4.96)$ & $(3.53)$ \\
\hline \multirow[t]{2}{*}{$\ln ($ Employees $)$} & $1.140 * * *$ & $1.165 * * *$ & $1.174 * * *$ & $0.887 * * *$ & $0.905^{* * *}$ & $0.913 * * *$ \\
\hline & $(46.09)$ & $(52.04)$ & $(55.77)$ & $(21.26)$ & $(22.86)$ & $(18.61)$ \\
\hline \multirow[t]{2}{*}{ Constant } & $11.18 * * *$ & $11.04 * * *$ & $11.25 * * *$ & $9.738 * * *$ & $9.728 * * *$ & $10.09 * * *$ \\
\hline & $(41.79)$ & $(18.85)$ & $(22.44)$ & $(23.36)$ & $(22.35)$ & $(18.86)$ \\
\hline Industry Controlled & Yes & Yes & Yes & Yes & Yes & Yes \\
\hline Region Controlled & Yes & Yes & Yes & Yes & Yes & Yes \\
\hline Year/Size Controlled & Yes & Yes & Yes & Yes & Yes & Yes \\
\hline Observations & 2031 & 2031 & 2031 & 4280 & 4280 & 4280 \\
\hline \multirow[t]{2}{*}{ Adjusted $\mathrm{R}^{2}$} & 0.651 & 0.698 & & 0.576 & 0.574 & \\
\hline & \multicolumn{3}{|c|}{ Importer \& Profitability } & \multicolumn{3}{|c|}{ Importer \& Profitability } \\
\hline $\ln$ (Operating Profit) & OLS & Robust OLS & Quantile & OLS & Robust OLS & Quantile \\
\hline \multirow[t]{2}{*}{ Importer } & $0.244 * *$ & 0.149 & $0.188 *$ & $0.952 * * *$ & $0.877 * * *$ & $0.873 * * *$ \\
\hline & $(2.98)$ & $(1.87)$ & $(2.56)$ & $(7.88)$ & (7.59) & $(6.41)$ \\
\hline \multirow[t]{2}{*}{$\ln$ (Employees) } & $1.182 * * *$ & $1.209 * * *$ & $1.190 * * *$ & $0.875^{* * *}$ & $0.895 * * *$ & $0.892 * * *$ \\
\hline & $(49.02)$ & $(55.00)$ & $(58.92)$ & $(21.11)$ & (22.70) & (19.13) \\
\hline \multirow[t]{2}{*}{ Constant } & $11.09 * * *$ & $10.95 * * *$ & $11.74 * * *$ & $9.772 * * *$ & $9.782 * * *$ & $10.13 * * *$ \\
\hline & (41.09) & $(18.55)$ & $(104.48)$ & $(23.71)$ & (22.69) & $(20.02)$ \\
\hline Industry Controlled & Yes & Yes & Yes & Yes & Yes & Yes \\
\hline Region Controlled & Yes & Yes & Yes & Yes & Yes & Yes \\
\hline Year/Size Controlled & Yes & Yes & Yes & Yes & Yes & Yes \\
\hline Observations & 2031 & 2031 & 2031 & 4280 & 4280 & 4280 \\
\hline Adjusted $\mathrm{R}^{2}$ & 0.645 & 0.694 & & 0.58 & 0.578 & \\
\hline
\end{tabular}

Note. Heteroscedasticity robust $\mathrm{t}$-statistics in parentheses. $* * *, * *$, and $*$ represent significance at $1 \%, 5 \%$, and $10 \%$ confidence levels, respectively. Year control is for the analysis of Manufacturing Surveys (1999-2003) and size control is for the analysis of Industrial Census (2007). 
Table 8. International trade and profitability (sales profit and rate of profit)

\begin{tabular}{|c|c|c|c|c|c|c|c|}
\hline \multicolumn{8}{|c|}{ Industrial Census (2007) } \\
\hline \multirow[b]{2}{*}{$\ln$ (Sales Profit) } & \multicolumn{3}{|c|}{ Two-Way Trader \& Profitability } & \multirow[b]{2}{*}{$\ln$ (Rate of Profit) } & \multicolumn{3}{|c|}{ Two-Way Trader \& Profitability } \\
\hline & OLS & Robust OLS & Quantile & & OLS & Robust OLS & Quantile \\
\hline \multirow[t]{2}{*}{ Two-Way Trader } & $0.675^{* * * *}$ & $0.570 * * *$ & $0.574 * * *$ & Two-Way Trader & $0.0466^{* * *}$ & $0.0311 * * *$ & $0.0322 * * *$ \\
\hline & $(22.09)$ & $(18.30)$ & $(16.17)$ & & $(11.45)$ & $(7.03)$ & $(5.93)$ \\
\hline \multirow[t]{2}{*}{$\ln$ (Employees) } & $1.298 * * *$ & $1.366^{* * * *}$ & $1.353 * * *$ & $\ln$ (Employees) & $-0.0665^{* * *}$ & $-0.0661 * * *$ & $-0.0741 * * *$ \\
\hline & $(164.08)$ & $(206.45)$ & $(179.54)$ & & $(-49.93)$ & $(-70.18)$ & $(-64.18)$ \\
\hline \multirow[t]{2}{*}{ Constant } & $11.58 * * *$ & $11.22 * * *$ & $10.21 * * *$ & Constant & $0.657 * * *$ & $0.688 * * *$ & $0.693 * * *$ \\
\hline & $(150.60)$ & $(144.47)$ & (99.26) & & $(46.86)$ & $(53.55)$ & $(53.04)$ \\
\hline Industry Controlled & Yes & Yes & Yes & Industry Controlled & Yes & Yes & Yes \\
\hline Region Controlled & Yes & Yes & Yes & Region Controlled & Yes & Yes & Yes \\
\hline Size Controlled & Yes & Yes & Yes & Size Controlled & Yes & Yes & Yes \\
\hline Observations & 49380 & 49380 & 49380 & Observations & 49011 & 49011 & 49011 \\
\hline \multirow[t]{2}{*}{ Adjusted $\mathrm{R}^{2}$} & 0.736 & 0.767 & & Adjusted $\mathrm{R}^{2}$ & 0.082 & 0.163 & \\
\hline & \multicolumn{3}{|c|}{ Exporter \& Profitability } & & \multicolumn{3}{|c|}{ Exporter \& Profitability } \\
\hline $\ln$ (Sales Profit) & OLS & Robust OLS & Quantile & $\ln$ (Rate of Profit) & OLS & Robust OLS & Quantile \\
\hline \multirow[t]{2}{*}{ Exporter } & $0.762 * * *$ & $0.619 * * *$ & $0.615 * * *$ & Exporter & $0.0525^{* * *}$ & $0.0394 * * *$ & $0.0446 * * *$ \\
\hline & $(29.18)$ & $(24.17)$ & $(22.09)$ & & $(12.94)$ & $(10.81)$ & $(10.34)$ \\
\hline \multirow[t]{2}{*}{$\ln$ (Employees) } & $1.283 * * *$ & $1.351 * * *$ & $1.342 * * *$ & $\ln$ (Employees) & $-0.0675^{* * *}$ & $-0.0670^{* * *}$ & $-0.0756^{* * *}$ \\
\hline & $(161.55)$ & $(203.62)$ & $(185.79)$ & & $(-50.40)$ & $(-70.82)$ & $(-67.51)$ \\
\hline \multirow[t]{2}{*}{ Constant } & $11.49 * * *$ & $11.16^{* * *}$ & $10.19 * * *$ & Constant & $0.653 * * *$ & $0.683 * * *$ & $0.688 * * *$ \\
\hline & $(150.04)$ & $(144.33)$ & $(104.45)$ & & $(46.68)$ & $(53.55)$ & $(54.69)$ \\
\hline Industry Controlled & Yes & Yes & Yes & Industry Controlled & Yes & Yes & Yes \\
\hline Region Controlled & Yes & Yes & Yes & Region Controlled & Yes & Yes & Yes \\
\hline Size Controlled & Yes & Yes & Yes & Size Controlled & Yes & Yes & Yes \\
\hline Observations & 49380 & 49380 & 49380 & Observations & 49011 & 49011 & 49011 \\
\hline \multirow[t]{2}{*}{ Adjusted $\mathrm{R}^{2}$} & 0.737 & 0.768 & & Adjusted $\mathrm{R}^{2}$ & 0.083 & 0.164 & \\
\hline & \multicolumn{3}{|c|}{ Importer \& Profitability } & & \multicolumn{3}{|c|}{ Importer \& Profitability } \\
\hline $\ln$ (Sales Profit) & OLS & Robust OLS & Quantile & $\ln$ (Rate of Profit) & OLS & Robust OLS & Quantile \\
\hline \multirow[t]{2}{*}{ Importer } & $0.752 * * *$ & $0.619 * * *$ & $0.595 * * *$ & Importer & $0.0448 * * *$ & $0.0287 * * *$ & $0.0347 * * *$ \\
\hline & (31.92) & $(26.08)$ & $(22.78)$ & & $(12.77)$ & $(8.49)$ & $(9.13)$ \\
\hline \multirow[t]{2}{*}{$\ln$ (Employees) } & $1.283^{* * *} *$ & $1.351^{* * *}$ & $1.339 * * *$ & $\ln ($ Employees $)$ & $-0.0673^{* * *}$ & $-0.0667 * * *$ & $-0.0749^{* * *}$ \\
\hline & (161.66) & (203.98) & (183.83) & & $(-50.22)$ & $(-70.48)$ & $(-70.65)$ \\
\hline \multirow[t]{2}{*}{ Constant } & $11.55^{* * *}$ & $11.21 * * *$ & $10.26 * * *$ & Constant & $0.664 * * *$ & $0.694 * * *$ & $0.697 * * *$ \\
\hline & (152.13) & (146.04) & (105.03) & & $(47.76)$ & (54.73) & (58.93) \\
\hline Industry Controlled & Yes & Yes & Yes & Industry Controlled & Yes & Yes & Yes \\
\hline Region Controlled & Yes & Yes & Yes & Region Controlled & Yes & Yes & Yes \\
\hline Size Controlled & Yes & Yes & Yes & Size Controlled & Yes & Yes & Yes \\
\hline Observations & 49380 & 49380 & 49380 & Observations & 49011 & 49011 & 49011 \\
\hline Adjusted $\mathrm{R}^{2}$ & 0.738 & 0.768 & & Adjusted $\mathrm{R}^{2}$ & 0.083 & 0.164 & \\
\hline
\end{tabular}

Note. Heteroscedasticity robust $\mathrm{t}$-statistics in parentheses. ***, **, and * represent significance at $1 \%, 5 \%$, and $10 \%$ confidence levels, respectively. 


\section{Conclusions}

In this paper, we directly address the question of whether or not international trading firms are more profitable in terms of various profit measures than their non-international trading counterparts. In other words, is it possible to identify trader profitability premia, similarly to what has been found for productivity?

From the empirical results, we document clear and positive profitability premia of international traders compared to non-traders that are large and statistically significant for the operating profit and the sales profit of the firm, but relatively smaller by the rate of profit measure. Specifically, the findings from our analysis suggest that international firm activities are strongly and positively correlated with firm profitability for the operating and sales profits. However, we also find that, though statistically significant, trader profitability premia in terms of the rate of profit are small in magnitude. This is in line with past studies (e.g., Fryges \& Wagner, 2010). Furthermore, regarding the control variables, our results reveal that firm size is one of the crucial indicators for firm-level profitability. This is also similar to previous studies (e.g., Wagner, 2012). In general, there exists statistically significant evidence for trader profitability premia in Thai manufacturing in our study. Exporters are often the most profitable (and are usually the most productive) groups of international traders, while two-way traders and importers are approximately the same on profit measures. Firms with no trade can be expected to be the least profitable groups. Our results further reveal that there is a positive correlation between various types of traders (two-way traders, only exporters and only importers) and firm profitability. Typically, engaging in exports (being an exporter) is heavily and positively correlated with an increase in the sales profit and the rate of profit of the firm. We conclude that productivity advantages of these international trading firms are not used up by the additional costs related with trade and the integration into the world market, and can be partly transmitted into profitability advantages of these firms (as revealed by the trader profitability premia). The evidence presented in this study for Thailand, a primary country in the international market for manufactured goods in the Southeast Asian region, is attention-grabbing on its own since the results can be served as a point of reference for future studies when using more enriched data from other countries, especially in the case for newly industrialized and developing countries. Nevertheless, the trader profitability premia in our analysis, as detected by estimating regression models using pooled data for traders and non-traders, cannot be interpreted as indicators for a direct causal effect of trade on profitability. On one hand, it might well be the case that there is self-selection of more productive and more profitable firms into exporting/importing markets. On the other hand, exporting/importing might increase profitability by learning from foreign customers and competitors. Apparently, for any given firm, both directions of causality might be important (Fryges \& Wagner, 2010). Due to data limitations, we cannot test these hypotheses since the data do not provide enough information regarding firm dynamics and survival.

Finally, future work should employ more advanced estimation techniques (i.e., the propensity score matching method, dynamic panel data analysis, and so forth) to provide more solid evidence for the Thai case. These are interesting points that cannot be examined due to restrictions of the dataset we have at the time of this analysis and are potential subjects of future research.

\section{Acknowledgments}

The author is grateful to Keio Economic Observatory (KEO) for providing the primary data set as well as members of the International Trade and Investment Seminar at Keio University for their support.

\section{References}

Foster, L., Haltiwanger, J., \& Syverson, C. (2008). Reallocation, Firm Turnover, and Efficiency: Selection on Productivity or Profitability? American Economic Review, 98(1), 394-425. http://dx.doi.org/10.1257/aer.98.1.394

Fryges, H., \& Wagner, J. (2010). Exports and Profitability: First Evidence for German Manufacturing Firms. The World Economy, 33(3), 399-423. http://dx.doi.org/10.1111/j.1467-9701.2010.01261.x

Girma, S., Görg, H., \& Strobl, E. (2004). Exports, International Investment, and Plant Performance: Evidence $\begin{array}{lllll}\text { from a Non-Parametric Test. Economics } & \text { Letters, 83(3), 317-324. }\end{array}$ http://dx.doi.org/10.1016/j.econlet.2003.10.024

Grazzi, M. (2012). Export and Firm Performance: Evidence on Productivity and Profitability of Italian Companies. Journal of Industry, Competition and Trade, 12(4), 413-444. http://dx.doi.org/10.1007/s10842-011-0102-9

Melitz, M. J., \& Ottaviano, G. I. (2008). Market Size, Trade, and Productivity. The Review of Economic Studies, 75(1), 295-316. http://dx.doi.org/10.1111/j.1467-937X.2007.00463.x 
Kox, H. L., \& Rojas-Romagosa, H. (2010). Exports and Productivity Selection Effects for Dutch Firms. De Economist, 158(3), 295-322. http://dx.doi.org/10.1007/s10645-010-9147-0

Ramstetter, E. D. (2004). Labor Productivity, Wages, Nationality, and Foreign Ownership Shares in Thai Manufacturing 1996-2000. Journal of Asian Economics, 14(6), 861-884. http://dx.doi.org/10.1016/j.asieco.2003.10.009

Temouri, Y., Vogel, A., \& Wagner, J. (2013). Self-Selection into Export Markets by Business Services Firms-Evidence from France, Germany and the United Kingdom. Structural Change and Economic Dynamics, 25, 146-158. http://dx.doi.org/10.1016/j.strueco.2012.02.004

Wagner, J. (2012). Exports, Imports and Profitability: First Evidence for Manufacturing Enterprises. Open Economies Review, 23(5), 747-765. http://dx.doi.org/10.1007/s11079-011-9235-z

Wagner, J. (2013). Exports, Imports and Firm Survival: First Evidence for Manufacturing Enterprises in Germany. Review of World Economics, 149(1), 113-130. http://dx.doi.org/10.1007/s10290-012-0141-2

Wagner, J. (2014). Exports and Firm Profitability: Quality Matters!. University of Lüneburg Working Paper Series in Economics, No. 296.

\section{Copyrights}

Copyright for this article is retained by the author(s), with first publication rights granted to the journal.

This is an open-access article distributed under the terms and conditions of the Creative Commons Attribution license (http://creativecommons.org/licenses/by/3.0/). 